Penultimate draft. Published in Studies in History and Philosophy of Biological and Biomedical Sciences, 2013, 44(3):278-286

If you do not have access to the final version feel free to ask me for a copy

adam.hochman83@gmail.com

\title{
Racial discrimination: How not to do it
}

\author{
Adam Hochman
}

\begin{abstract}
The UNESCO Statements on Race of the early 1950s are understood to have marked a consensus amongst natural scientists and social scientists that 'race' is a social construct. Human biological diversity was shown to be predominantly clinal, or gradual, not discreet, and clustered, as racial naturalism implied. From the seventies social constructionists added that the vast majority of human genetic diversity resides within any given racialised group. While social constructionism about race became the majority consensus view on the topic, social constructionism has always had its critics. Neven Sesardic (2010) has compiled these criticisms into one of the strongest defences of racial naturalism in recent times. In this paper I argue that Sesardic equivocates between two versions of racial naturalism: a weak version and a strong version. As I shall argue, the strong version is not supported by the relevant science. The weak version, on the other hand, does not contrast properly with what social constructionists think about 'race'. By leaning on this weak view Sesardic's racial naturalism intermittently gains an appearance of plausibility, but this view is too weak to revive racial naturalism. As Sesardic demonstrates, there are new arguments for racial naturalism post-Human Genome Diversity Project. The positive message behind my critique is how to be a social constructionist about race in the post-genomic era.
\end{abstract}

\section{Introduction}

In his recent article Race: a social destruction of a biological concept, Sesardic argues that social constructionists have been 'refuting' a straw-man characterisation of racial naturalism, the view that 'race' is a legitimate biological category (Sesardic 2010). Social 
constructionists have burdened the concept of race, he claims, with clearly unacceptable essentialist connotations; all with the aim of dismissing it outright. In light of the modern synthesis, with its rejection of species essentialism, we are committed to the rejection of racial essentialism. The task for race naturalists, then, is to develop a "biologically informed but non-essentialist concept of race" (Sesardic 2010, 146).

But what are race naturalists made of, if not straw? In this paper I ask whether Sesardic's attempt at rehabilitating a biological concept of race is successful. My answer is firmly negative. Sesardic equivocates between two versions of racial naturalism. One of these is so weak that it does not properly contrast with any plausible version of social constructionism about race, the view that racial categories are arbitrary with respect to the (relatively meagre) biological diversity that they seek to describe, reflecting social practice, and social prejudice, more effectively than biological difference. The other version of racial naturalism is much stronger, but it is not supported by studies of human biological diversity. This paper offers a rebuttal of Sesardic's argument; one that is complementary to, and expands upon, that offered by Peter Taylor (2011) in his short discussion note on the same article. Underlying the critical argument is a positive message: how to be a social constructionist about race in the postgenomic era.

Sesardic's article can be seen as a three-pronged attack on social constructionism about race. The first prong is an argument from forensic anthropology. The second prong is an argument from genetic clustering studies. The third prong is not really an argument at all. This is Sesardic's intimation that there might be genetically determined psychological and moral differences between the so-called 'races'. His claim is not so much that there are such differences, but rather that there are not not such differences. He does not describe any empirical studies that suggest that there are genetically determined psychological or moral differences between racialised groups, focusing instead on what he sees as the poor quality of argument against this position.

For the purposes of this paper I will ignore the third prong. I cannot image anyone unpersuaded by Sesardic's main argument - that the human species is divisible into a small number of subspecies, or races - being convinced on the basis of this part of his article. While claims of moral and intellectual superiority should be opposed, the focus of the present paper is to challenge the racialist underpinning Sesardic attempts to legitimise them with. The third prong is a particularly pungent red herring, but my focus will be on critiquing Sesardic's central arguments for racial naturalism. 
In the two following sections I question the evidentiary basis of Sesardic's attempted revival of a biological concept of race, taking on the arguments from forensic anthropology and genetic anthropology in turn. In the final section before the conclusion I map out the rhetorical terrain of Sesardic's racial naturalism, with an emphasis on the role flip-flopping between a weak and a strong position plays in his argumentation. Susan Oyama (2000, p. 31) famously compared disputing genetic determinism to fighting the undead. Racial naturalism also has this tendency to rise from the grave. If there is to be a "stake in the heart move" in the race debate it is not going to be based on biological facts alone.

\section{Why forensic anthropologists are so good at identifying social constructs}

The problem forensic anthropology presents to social constructionism about race is simple. Forensic anthropologists are very good at assigning human remains to the racialised group with which the deceased would have been identified when he or she was alive. Social constructionists, on the other hand, argue that racial categories are poor proxies for biological (in this case morphological) diversity. The facts of forensic anthropology and the theory of social constructionism seem to be at odds. This problem for social constructionism, writes Sesardic, "prompted one bewildered and exasperated scientist to write an article with a provocative title" (2010, 156): If Races Do Not Exist, Why Are Forensic Anthropologists So Good at Identifying Them? (Sauer 1992).

The irony is that if Norman Sauer could be said to be bewildered and exasperated about anything, or anyone, it would be about race naturalists, not social constructionists. Sesardic reads Sauer's title as if it were a rhetorical question; as if Sauer is himself a race naturalist, deriding social constructionists for being so muddled-headed. This could not be further from the truth. Sauer is himself a social constructionist about race. He asks a question in his title, a question which presents a problem for social constructionism, and then, in the body of the paper, he answers it.

But more on the problem. According to Sauer, "Most anthropologists have abandoned the concept of race as a research tool and as a valid representation of human biological diversity" (1992, 107). Yet, as Sauer recognizes, "the race concept as it is used by the public continues to be one of the central foci of forensic anthropological research and application" (Sauer 1992, 107). Along with age, sex and stature, 'race' is a part of the profile used by forensic anthropologists to help them identify victims. And it can help, at least some of the 
time. Sauer cites Snow et al. (1979), who were able to correctly identify 22 out of 27 'white crania' and 7 out of 8 'black crania', but only 1 out 7 'Native American crania'.

Yet Sauer maintains that "the successful assignment of race to a skeletal specimen is not a vindication of the race concept, but rather a prediction that an individual, while alive was assigned to a particular socially constructed 'racial' category" $(1992,107)$. Why does Sauer insist on social constructionism, given evidence that, on the face of it, seems to support racial naturalism? His reason is that the practice of matching remains to racial labels, and then to victims, has little, if anything to do with questions of taxonomic significance. "Some of the confusion about this issue", suggests Sauer,

may stem from an assumption that to identify a specimen as having ancestors in Africa or Europe, for example, is tantamount to race identification and a verification of geographic races. No one who argues against the race concept denies that human variation exists or claims that this variation is not systematic. In fact, it is systematic variation that allows anyone to estimate, with varying degrees of specificity, a person's place of ancestry from their physical features. However, to identify a person as having ancestors from, say, Northern Europe does not identify a biological race of Northern Europeans. (Sauer 1992, 110)

Of course there is morphological variation, explains Sauer, and of course this variation has some systematic structure - otherwise forensic anthropologists would not be able to do their job - but this structure does not map on to traditional racial categories, so forensic anthropology does not support racial naturalism.

Ousley, Jantz, and Freid (2009) set out to test Sauer's conclusion empirically. Their preliminary findings seemed to support racial naturalism, and indeed Sesardic cites their article in favour of his view. Ousley and colleagues were able to sort skulls from North American black males and North American white males into these respective categories with 97\% accuracy. When black, white, Chinese and Native American male skulls were analysed $96 \%$ were correctly allocated to their groups. The success rate dropped slightly to $84 \%$ when Japanese skulls were analysed instead of Chinese skulls, because the skulls of Japanese males and North American black males sometimes misclassified as each other. So far so good for racial naturalism. Black, white, Asian, Native American; these are all traditional racial categories. 
The picture changed, however, when more populations were analysed. When Japanese, Chinese and Vietnamese skulls were measured, Ousley and colleagues correctly allocated $80 \%$ of the skulls to their groups, even though the Japanese, Chinese and Vietnamese are traditionally supposed to belong to the same 'race'. Similarly, $87 \%$ of the skulls from Arikara females and Sioux females were correctly sorted, and 94\% of the skulls from Nagasaki males and Tohoku males were correctly sorted. Does this mean that there is more than one Native American race, and that there are two Japanese races, a southern and a northern? These questions seems foolish when we consider that Ousley et al. were able to distinguish between the skulls of white males born between 1840 and 1890 and white males born between 1930 and 1980 with $96 \%$ accuracy. Surely nobody would claim that there was a late nineteenth century 'white race', which died out, giving rise to an early twentieth century 'white race'.

For the race naturalist, such as Sesardic, the difference between 'white skulls', 'black skulls', 'Asian skulls' and 'Native American skulls' is a racial one. Yet Ousley et al. were able to distinguish between groups that are not separated 'racially', but culturally, linguistically, politically, and temporally, and at a finer grain than a racial taxonomy offers. Racial categories are only one way of grouping humans, and an imprecise one at that. This reveals a confirmation bias on the part of the race naturalist (Ousley et al. 2009, 74). In evaluating any scientific theory we need to consider evidence that would confirm and evidence that would disconfirm that theory. When skulls are sorted accurately according to 'race' it seems as though racial naturalism finds support from forensic anthropology. But the disconfirming evidence, which demonstrates that 'racial' divisions offer an arbitrary representation of human morphological diversity, is devastating to racial naturalism; or at least to racial naturalism that seeks support from forensic anthropology.

Human morphology varies, and this variation is often systematic enough to allow for classification. There are many ways in which we can divide humans into groups: by language, by location, by culture, by tribe, by time, by 'race'. All of these groupings will latch on to human morphological variation in some ways, and not others. Forensic anthropologists are biased towards racial classification, but this is because we, the public, tend to classify (our missing persons) racially, not because it is the best naturalistic representation of human morphological diversity. Forensic anthropology is a practical field. Forensic anthropologists translate trait measurements to the labelling systems societies use, or would have used, to describe missing persons. It does not matter, from a forensic point of view, whether the labelling systems are accepted scientific taxonomies, as long as there is a correlation between measurements and the classification systems used in any given society. 
From a taxonomic point of view, however, and also from a social point of view, it does matter whether racial language is used in scientific contexts. Sauer's article is an appeal to forensic anthropologists for awareness about these issues:

Perhaps we could avoid the term "race" in our communications about cases, substituting 'ancestry' or some other word that has less baggage than race. Perhaps we could be more explicit about the social or cultural concepts of race. Certainly we can teach the non-existence of race in the classroom and do our best to clarify the use of races in forensic anthropology. (Sauer 1992, 110)

Also in a deflationary vein, Ousley et al. argue that there are "so many possible distinctive biological races that the concept is virtually meaningless" $(2009,74)$. Why, given such strong statements against racial classification, does Sesardic appeal to Sauer and Ousley et al. in favour of racial naturalism?

Given that Sesardic describes only the aspects of these articles that seem to favour racial naturalism, overlooking the main arguments and key findings, the most obvious - but least charitable - answer is that Sesardic favours persuasion over other academic virtues. Indeed unless one takes the trouble to read the source articles Sesardic's section on 'morphological differences' is quite compelling. Regardless of whether or not there is a grain of truth in this answer there are more charitable and more enlightening reasons for Sesardic's appeal to forensic anthropology.

One reason Sesardic is drawn to forensic anthropology is that its methods parallel those recently developed in genetic anthropology, a field which he also interprets as supporting racial naturalism. Genetic anthropology has seen a shift, over the last decade or so, from single-locus statistics to multi-locus statistics (statistics that take into account correlation data). Where single-locus studies were used by social constructionists, most notably Lewontin (1972), to argue against racial naturalism, Sesardic uses multi-locus studies to argue for racial naturalism. But this is the subject of the following section. I mention it here because modern forensic anthropology, like recent genetic anthropology, uses multivariate statistical analysis. For Sesardic, following Mitton (1977)and Edwards (2003), multivariate statistical analysis is the key to scientific racial classification.

So Sesardic begins his section on morphological differences by pointing out that one of the common arguments against racial naturalism, the 'independent variation argument', relies on single variable statistics. As Robin Andreason explains this argument, 
a classification based on skin color may cross-classify one based on blood type. Both classifications may disagree with one that is based on propensity towards a certain disease. This problem is said to be compounded as more and more traits are added to the classification scheme. If one trait is used (e.g., skin color), it may be possible to provide an unambiguous classification scheme. If two traits are used (e.g., skin color and blood type), it may still be possible - but there will be some problem cases. As the number of traits increases, racial classification becomes increasingly difficult. $(2004,428)$

Classification becomes increasingly difficult when more variables are analysed using single variable statistics, so long as those variables are not perfectly correlated. However, forensic anthropologists are able to identify victims with greater accuracy the more variables they analyse. For example, Ousley and colleagues analysed between 7 and 25 craniometric measures in the study I described. Their success lay in their use of multivariate statistical analysis; in the correlation of their measures, in the finding of trends. Sesardic argues that forensic anthropology undermines the independent variation argument by showing, contra Andreason, that as the number of traits increases, racial classification becomes easier and easier.

The success of Sesardic's criticism depends on how 'racial classification' is understood. The title of Guido Barbujani's 2005 article Human Races: Classifying People vs Understanding Diversity is helpful here. Ideally, classification systems are good guides to diversity. Certainly scientific classification systems should have this feature. But accurate classification and an understanding of diversity do not necessarily go hand in hand. Take this toy example. We could classify ripe fruit based on the colour of its skin. Yellow fruits would include bananas and lemons. Red fruits would include strawberries and cherries. This classification system would be stable enough, but it would offer a poor representation of fruit diversity. It follows that classification systems - even reliable classification systems - are not necessarily useful guides to diversity.

Sesardic is correct in claiming that traits can vary independently from one another and that classification is still possible, although I suspect the independent variation argument still stands when comparing different kinds of traits (i.e. not just skull measurements). However, he is wrong to assume that the race debate hangs on the issue of classification alone, as classification systems can offer poor representations of diversity. Race naturalists need to 
show that racial classification is a good guide to human biological variation. They will not find any support from forensic anthropology.

\section{Genetic clustering and the illusion of biological race}

The resurgence of racial naturalism over the last decade is due not so much to forensic anthropology, but rather to genetic anthropology. Until recently, genetic diversity studies seemed to provide unambiguous support for social constructionism about race. Most famous is Lewontin's 1972 article The Apportionment of Human Diversity in which he demonstrated that, on a locus-by-locus basis, around $85.4 \%$ of the overall human genetic diversity resides within any given continental population, so roughly within the so-called 'races'. Another $8.3 \%$ of our genetic diversity, he showed, is accounted for by genetic variation within racialised groups. The remaining $6.3 \%$ of the total human genetic diversity is specific to those groups. Lewontin concluded that "Racial classification is now seen to be of virtually no genetic or taxonomic significance" $(1972,397)$, and most scientists and philosophers thought he was right.

Most still do, I think, but racial naturalism is making resurgence. Much of its momentum is drawn from A.W.F. Edwards' 2003 article Human genetic diversity: Lewontin's fallacy, even though, as Sesardic correctly points out, the same argument against Lewontin was made in 1977 by Jeffry Mitton (seemingly unbeknownst to Edwards). According to Mitton and Edwards, Lewontin's error - Edwards calls it his 'fallacy' - was to analyse genetic data on the assumption that it contains no information of taxonomic relevance beyond that revealed by a locus-by-locus analysis. "The 'taxonomic significance' of genetic data", writes Edwards, "in fact often arises from correlations amongst the different loci, for it is these that may contain the information which enables a stable classification to be uncovered" $(2003,799)$.

Lewontin showed us that people from all over the world are very similar, genetically. Race naturalists do not dispute this. They argue, instead, that the patterns of difference are structured along racial lines. The idea is not that the 'races' are more genetically diverse than Lewontin presumed, but rather that the structure of our meagre diversity is captured by racial classification.

If Edwards' 2003 article on 'Lewontin's fallacy' provided the theoretical support for a revival of racial naturalism, Rosenberg et al.'s 2002 article on the Genetic Structure of Human Populations provided the scientific support; although the authors themselves disavow 
a racial interpretation of their work in a later paper: "Our evidence for clustering", they write, "should not be taken as evidence of our support of any particular concept of "biological race"” (Rosenberg et al. 2005, 668). They further claim that, "The arguments about the existence or non-existence of "biological races" in the absence of a specific context are largely orthogonal to the question of scientific utility" $(2005,669)$. I will take a stronger position, arguing that despite the prima facie support genetic anthropology offers to racial naturalism, the recent genetic clustering studies actually support social constructionism about race (see also Hochman, forthcoming).

Here is what Rosenberg and colleagues found. With access to samples from 52 populations, Rosenberg and his team attempted to infer worldwide population structure at five different grains of analysis, using the multivariate statistical program STRUCTURE. The 52 populations were divided into seven regions: Africa, Europe, the Middle East, Central/South Asia, East Asia, Oceania, and America. At $K=2$, the roughest grain of analysis, where the program was set to distinguish two groups, the clusters were anchored by Africa and America. At $K=5$, when the program was set to distinguish five groups, genotypes from Europe, the Middle East, Central Asia and South Asia were clustered together, and those from the other four regions were clustered separately. At the finest grain of analysis, $K=6$, the Kalash of northwest Pakistan were added as a sixth distinct cluster.

Sesardic, following Edwards, argues that this study provides strong evidence for racial naturalism. Indeed Risch et al. propose that "these population genetic studies have recapitulated the classical definition of races based on continental ancestry" $(2002,3)$. It must be admitted that, on first glance, Rosenberg et al.'s 2002 does at least appear to offer some support to racial naturalism. While, as Barbujani $(2005,7)$ points out, the inferred clusters do not correspond to any previously proposed racial classification, they are not that far off the mark (most gene-centred race naturalists believe that science will vindicate something like a traditional racial taxonomy). And while many of the individuals sampled have substantial mixed cluster membership, this is not deemed to be a problem for the new racial naturalism, which, recall, is non-essentialist.

But not all have interpreted Rosenberg et al.'s work racially (most notably the authors themselves). I will present three main lines of argument that have been developed against a racial reading of clustering studies, with no assumption that they are exhaustive. These arguments point out that such a reading (i) suffers from a grain of resolution problem, (ii) overlooks the non-concordance between clustering studies, and (iii) ignores the clinal, or gradual, distribution of genetic structure and diversity. These arguments, taken together, lead 
to the conclusion that thinking racially is not a very good way to think about human biological diversity.

The grain of resolution problem has been recognised by a number of social constructionists about race (Gannett 2004, 336-336; Barbujani 2005, 6-7; Kitcher 2007, 305). However, it is a card-carrying race naturalist, Armand Leroi, who describes this problem best:

there is nothing very fundamental about the concept of the major continental races; they're just the easiest way to divide things up. Study enough genes in enough people and one could sort the world's population into 10, 100, perhaps 1000 groups, each located somewhere on the map. $(2005,4)$

It is reflective of the confusion in the race debate that Leroi finds this statement consistent with racial naturalism. Social constructionists, myself included, take this as strong support for social constructionism about race. Putting aside the exaggeration of Leroi's claim - most of us would be spread across the map - the arbitrariness of a rough grain of analysis is surely a problem for racial naturalism.

In the Rosenberg et al. study there were five grains of analysis, each producing different clusters. How is the race naturalist to decide which is the 'right' grain of analysis, or how many races there are? Are the Kalash of northwest Pakistan, who were separated on the finest grain of analysis, supposed to be a race, for instance? And how are we to interpret Rosenberg et al.'s within-continent analysis, which showed almost as much structure as the betweencontinent analysis? At $K=4$ the African San, Mbuti Pygmy, and Biaka Pygmy formed distinct clusters, while the Bantu (Kenya), Mandenka, and Yoruba were clustered together. On a racial reading of the Rosenberg et al. study is there one sub-Saharan African race, or many? It is unclear how the race naturalist would answer this question.

When we consider other clustering studies the grain of resolution problem intensifies, and we also see the discord between studies. Li et al. (2008) identified a 'Central/South Asia cluster' and a 'Middle Eastern cluster' at $K=7$, neither of which were found by Rosenberg et al. (2002) at $K=6$ (note that all individuals in the Middle Eastern cluster had about 50\% membership in other clusters). Kalash individuals, in this study, appear to belong to the 'Central/South Asia' cluster with almost 100\% probability. In another study Tishkoff et al. (2009) analysed the structure of worldwide populations from $K=2$ to $K=14$, adding genotypes from Africa, India, Oceania, and the U.S. which were not used in the Rosenberg et 
al. study. Five of the seven clusters at $K=7$ were sub-Saharan African. A racial reading of this would tell us that there is one Saharan African/European/Middle Eastern/Central Asian/Indian race, one Eastern Asian/Oceanic/American race, and five sub-Saharan African races. At $K=14$ things start looking quite messy, but well over half of the clusters are still African. Perhaps needless to say, this is a real problem for racial naturalism. If the race naturalist cannot name and number the so-called races with any specificity or reliability, and on any well-grounded basis, racial naturalism is in trouble.

Another problem for racial naturalism is clinal, or gradual, variation. As George Gaylord Simpson wrote in 1943 ,

...there are species in which only the most restricted groups - point rather than area groups - are at all homogeneous and the intergradation is essentially continuous from one end of the species to the other, although the ends may be quite different. In such groups, the clines of Julian Huxley (1938), there is no natural number of subspecies and no way to delimit them that is not arbitrary. $(1943,149)$

Clinal variation presents a problem for racial division. In their 2004 article Evidence for Gradients of Human Genetic Diversity Within and Among Continents Serre and Pääbo argue that differences in study design can drastically affect how genetic diversity and structure are represented. When individuals are sampled from geographically contiguous locations, human genetic diversity and structure appear to be distributed in a cline which is "only occasionally disrupted by local discontinuities corresponding to linguistic or geographical barriers" (Serre and Pääbo 2004, 1679). On the other hand, when individuals are sampled from geographically distant populations, human genetic diversity and structure appear to be distributed in clusters. Serre and Pääbo argue that the evidence for clustering found by Rosenberg et al. was a result of their sample scheme, and that if we want to know whether the genetic structure of worldwide populations is smooth and clinal, or discreet and clustered, we had better sample individual genotypes from geographically contiguous locations, so that the clinal hypothesis can be tested.

In response to Serre and Pääbo (2004) Rosenberg et al. (2005) argued that while clinal and clustered representations appear to be mutually exclusive, they are in fact compatible. They agree with Serre and Pääbo that the genetic structure of human populations is predominantly clinal, but they argue that "clusters arise not as an artifact of the sampling scheme, but from small discontinuous jumps in genetic distance for most population pairs on 
opposite sides of geographic barriers" (Rosenberg et al. 2005, 660). Geographic barriers oceans, mountains, deserts - have also been barriers to gene flow. It is around these barriers that the clusters found by Rosenberg et al. (2002) were formed. They reflect shallow cuts in our predominantly clinal genetic variation and population structure.

Rosenberg et al. maintain that genetic clusters "match major geographic subdivisions of the globe", but, as we have already seen, there is discord between genetic clustering studies concerning the 'proper' number and location of genetic clusters. Recall that at $K=7$ Tishkoff et al. found five of the seven clusters within sub-Saharan Africa. Nearly all of the clusters were within a major geographic subdivision. This should not be surprising, given that the average nucleotide diversity within Africans almost doubles that found within Asians and Europeans (Yu et al. 2002). Even if a racial reading of Rosenberg et al. (2002) did not suffer from a grain of resolution problem, and if there were a concordance between clustering studies, the genetic difference between Africans within the sub-Saharan African cluster may well exceed that between individuals from different continents. A racial interpretation of Rosenberg et al.'s sub-Saharan African cluster misrepresents what we now know about genetic diversity.

We do not need to choose between clinal models of genetic structure and diversity and clustered models because the two are not mutually exclusive. One of the problems with 'race' is that it is a decidedly clustered representation of diversity. The race naturalist needs to make a case for privileging a strictly clustered representation of population structure. Sesardic describes Rosenberg et al.'s 2002 clustering study as "an important discovery that makes it much more difficult than before to claim that race is entirely disconnected from genetics" $(2010,153)$. This is simply too weak a position to revive racial science. After all, Lewontin showed that individuals from different continents are slightly more genetically different from each other than from individuals from the same continent. Insofar as 'race' is correlated with geographic ancestry you could conclude from this that racialised groups are not "entirely disconnected from genetics". Yet Lewontin's work has been widely interpreted as support for social constructionism, not racial naturalism. The message of Lewontin's paper was not that 'race' is completely disconnected from genetics, but rather that the so-called races overlap too much to justify a racial taxonomy.

The continental clusters that the 'new breed' of race naturalists appeal to do not accurately represent the nature of human genetic diversity and population structure. Genetic clustering is a real phenomenon, but to privilege these clusters as 'racial' is to reify them. It is more accurate to say, following Lewontin, that human genetic diversity is largely overlapping 
and, following Serre and Pääbo, that our genetic structure is predominantly clinal, with small discontinuities that correspond to geographical and linguistic barriers. These are the major features of human genetic diversity and structure, and they are not captured by race.

Sesardic notes that there have been some attempts to downplay a racial reading of Rosenberg et al.'s findings. Barbujani, for instance, points out that the subjects were not asked to self-report their race, so the race naturalist claim that genetic clusters coincide closely with self-identified race stands untested (Barbujani 2005). Sesardic claims that a study by Tang et al. (2005) cast doubt on Barbujani's criticism. This study included four populations of self-identified white, African American, East Asian, and Hispanic people living in the United States and Taiwan. Tang and her team were able to correctly allocate 3631 of 3636 subjects to these groups based on cluster membership alone. But Tang et al.'s results do not speak to Barbujani's criticism because the sample size is simply too small. Tang and colleagues analysed samples from 4 pre-defined populations. Rosenberg et al. analysed samples from 52. Moreover, the samples were taken from only two countries (the United States and Taiwan) and it is well known that U.S. racial categories differ from those employed by other nations (see Lee et al. 2001). Labels such as 'Hispanic' are especially context dependent. Someone who self-identifies as Hispanic on a U.S. census form may selfidentify as 'Mestizo' in other contexts. 'Mestizo' literally means 'mixed race'.

We should not be impressed by Tang et al.'s findings because, apart from the Hispanics, the populations sampled have such distinct, geographically distant, ancestries. The clustering of Hispanics is somewhat surprising because 'Hispanic' is a heterogeneous grouping. Hispanic individuals have varying mixtures of Native American, African and European ancestry. As Tang et al. mention, previous studies have not been able to allocate Hispanics to a distinct cluster. What accounts for their success? The explanation lies in the fact that the Hispanics sampled were all Texan Mexicans. If a more representative Hispanic sample were used, Tang's team would probably not have been able to correctly allocate the self-identified Hispanics. Mexicans have high proportions of Native American ancestry. Puerto Ricans, on the other hand, have substantial African ancestry. If Puerto Ricans (or other Hispanic populations) were included in the sample, they would probably not have clustered neatly with the Texan Mexicans.

While the Tang et al. paper may appear, at first glance, to support racial naturalism, it actually serves to highlight some of its major flaws. Note the sampling scheme. People who self-identify as white, African American and East Asian have ancestors from geographically distant parts of the world. Tang et al.'s study does not demonstrate that allele frequencies are 
discontinuous in a way that supports a racial taxonomy, because the continuity of allele frequency differences was not tested for. In reality, the criticism by Barbujani that Sesardic cites is the least of the worries for a racial interpretation of Tang et al., and Sesardic himself acknowledges this:

Questions can be (and have been) raised about whether the same outcome would be obtained for other racial categories, or with a sample of people with more mixed ancestries, or on a more fine-grained scale, etc. My point is merely that in view of these new studies it becomes harder to accept the widespread but often unsubstantiated claim about the biological meaninglessness of race. (Sesardic 2010, 154)

Here we see a retreat to a weak version racial naturalism, a position which, as I shall argue in the following section, does not properly contrast with social constructionism about race.

Let us consider one final scientific study that Sesardic appeals to in his attempt to revive racial naturalism. "A good measure of the robustness of racial genetic differentiation", writes Sesardic,

is the answer to the following question: "How often does it happen that a pair of individuals from one population is genetically more dissimilar than two individuals chosen from two different populations?" In fact, if many thousands of loci are used as a basis for judging genetic similarity and when individuals are sampled from geographically separated populations, the correct answer, which many will probably find surprising, is: "Never" (Witherspoon et al. 2007, 357). (Sesardic 2010)

The frequency $-\omega-$ with which individuals from different populations are more genetically similar than individuals from the same population is dependent on the number of loci analysed and the nature of the populations. Witherspoon et al. (2007) found that given 10 loci from geographically separated populations, $\omega \cong 30 \%$. In other words, when analysing 10 loci, two individuals from the same population are more genetically different from each other than from individuals from another population nearly one-third of the time. Given 100 loci sampled from geographically separated populations, $\omega \cong 20 \%$. Even when sampling 1000 loci geographically separated populations, $\omega \cong 10 \%$. However, when individuals from geographically (and historically) separated populations are sampled, and many thousands of 
loci are used, two individuals from different population are always more genetically diverse than two individuals from the same population (Witherspoon et al. 2007). This is the finding Sesardic highlights in the quote above.

It is hard to see how these findings could offer support to racial naturalism. As Bamshad et al. $(2004,602)$ observe, it is often mistakenly contented that the much higher within-group than between-group genetic variance (on a continental scale) shows that differences between individuals within groups are greater than those between groups, when this finding actually shows that individuals from different populations are, on average, slightly more genetically different from each other than are individuals from the same population. We should not expect individuals from geographically and historically separated groups to be more genetically different from each other than from individuals from other regions, except in cases where within-group diversity is especially high (e.g. sub-Saharan Africa).

The news that Witherspoon et al. bring is not, as Sesardic suggests, that 'race' is robust, but rather that we should be especially careful when making inferences about the genetic differences between individuals, and the phenotypic effects of these differences, based on knowledge about geographic ancestry. Witherspoon and colleagues ask us to imagine a (highly idealised) phenotype determined by loci of equal, additive effects, with a worldwide distribution similar to that found in their data set. As they explain, the proportion of individuals more phenotypically similar to someone from another population than to their own will mirror the $\omega$ values found in their study. That is, if the phenotype is determined by 12 loci, two individuals from geographically and historically separated populations will be more phenotypically similar to each other than to individuals from the same population around $31 \%$ of the time (Witherspoon et al. 2007, 358).

Notice again that we are talking about geographically separated populations. Witherspoon et al. $(2007,358)$ acknowledge that a more representative (larger, more evenly distributed) sample would have produced much higher $\omega$ values.

Many factors will further weaken the correlation between an individual's phenotype and their geographic ancestry. These include considering more closely related or admixed populations, studying phenotypes influenced by fewer loci, unevenly distributed effects across loci, nonadditive effects, developmental and environmental effects, and uncertainties about individuals' ancestry and actual populations of origin. (Witherspoon et al. 2007, 358) 
They also argue that, "Although many concepts of race are correlated with geographic ancestry, the two are not interchangeable, and relying on racial classifications will reduce predictive power still further" (Witherspoon et al. 2007, 358). On a close investigation of Witherspoon et al.'s 2007 it is hard to justify an interpretation of this study as a key source for racial naturalism.

\section{A field-guide for traversing the rhetorical landscape of racial naturalism}

It is one of the main contentions of this paper that Sesardic oscillates between two versions of racial naturalism; one which is strong but not supported by the science, and another which is so weak that it does not contradict social constructionism about race. The strong version claims that race is a privileged, objective, scientific representation of human biological diversity, and that there are a handful of geographically defined races. This is the racial naturalism that I have been contesting so far. The weak version claims that race is correlated with various biological traits, so race has a 'biological reality', but it is implied that the numbering of races will be arbitrary. This distinction does not usefully apply to other naturalistic accounts of race (e.g. Pigliucci and Kaplan 2003; Andreasen 2004), but I shall argue that it is vital to understand - and to counter - Sesardic's racial naturalism.

Advocating the strong version Sesardic claims that, "multiplying relevant phenotypic racial traits brings more order and structure, and indeed lays ground for an objective biological classification" (2010, 156; emphasis in original). This strong version of racial naturalism is not supported by forensic anthropology because, as Ousley et al. so clearly explain, "forensic analysis produces practical information useful for forensic identification, while a biological analysis provides insight about relationships among arbitrarily defined populations, which may be defined by social races, breeding populations, language, nationality, time periods, and other criteria" $(2009,73)$. As I showed in the previous section, the same is true in genetic anthropology. Racial classification is anything but objective.

Advocating the weak version of racial naturalism, Sesardic claims that races differ systematically "with respect to some genetically determined morphological characteristics (skin color, hair texture, facial features, etc.), with these morphological differences being the basis for the common-sense racial recognition and classification" (Sesardic 2010, 144). This statement does not actually conflict with social constructionism about race (although the 
social constructionist would substitute 'common-sense' with 'common practice'). Lisa Gannett writes that for the constructionist, "race is socially constructed by enlisting biological differences and investing these with socio-cultural meanings" (2010, 375). Social constructionists do not shut their eyes and claim that everyone, everywhere, is phenotypically identical. The claim is rather that traditional racial categories offer a poor representation of biological diversity, and that the reasons behind their creation and maintenance are not captured by a purely scientific perspective.

How then are we to charitably characterise Sesardic's position? If we focus on his strong version of racial naturalism it is not supported by the science. If we focus on his weak version he is arguing against a straw-man characterisation of social constructionism. But perhaps sophisticated social constructionists, like Gannett, are not Sesardic's target:

Learned societies issued statements disowning the concept [of race] and many leading experts in the relevant fields joined in by insisting that this pure "social construction" has no counterpart in the subject matter of life sciences, that "the concept of race has no genetic or scientific basis" (Craig Venter), or that it is "biologically meaningless" (Schwartz 2001, 1392). (Sesardic 2010, 144)

Perhaps a more charitable interpretation of Sesardic sees him as challenging 'pure social constructionists'; those who believe that 'race' has no correlation to any biological trait whatsoever. However, neither Venter nor Schwartz actually subscribe to this view. Venter's statement, made in a speech announcing the completion of a draft sequence of the human genome, was made in the context of this finding; that all humans have genome sequences that are $99.9 \%$ identical. Venter is not a pure social constructionist; he just believes that .1\% genetic difference between people is not enough to support racial naturalism.

Schwartz does indeed claim that race is "biologically meaningless"; perhaps he is a better candidate for 'pure social constructionism'. A glance at his article would prove this to be false. "Some geographically or culturally isolated populations", writes Schwartz,

can properly be studied for genetic influences on physiological phenomena or diseases. The Pima Indians, who have unusual susceptibility to noninsulin-dependent diabetes mellitus, and the people of Gambia, in whom polymorphisms in the NRAMPI gene influence susceptibility to tuberculosis, are examples... In central and western Africa... several independent mutations in the beta-globin gene gave rise to different 
sickle hemoglobins, each with a distinct geographic distribution and phenotype. These mutations spread through the population because they protect against malaria; they were dispersed in Greece, Saudi Arabia, Turkey, Iran, and elsewhere by migration and slavery. (Schwartz 2001, 1392-1393)

The message of Schwartz's article is not that 'race' is uncorrelated with disease, but rather that the connection between 'race' and disease is too weak to be of use in medical research. In all of the examples above 'race' fails to capture the populations of interest. Pima Indians and Gambians are populations within racialised groups. Mutated beta-globin genes are found between racialised groups. Meaning always takes place in context. When Schwartz writes that race is 'biologically meaningless' he means that it 'is not a scientifically valid biologically category'. He is not a 'pure social constructionist'. If 'pure social constructionism' is the target, it is unclear who its adherents are.

Perhaps the most striking difference between the weak and the strong version of racial naturalism has to do with the enumeration of the so-called races. Sesardic sees himself as following in Dobzhansky's footsteps, yet he fails to recognise a fundamental difference between Dobzhansky and himself. According to Dobzhansky, "Races are defined as populations differing in the incidence of certain genes, but actually exchanging or potentially able to exchange genes across whatever boundaries separate them" (1944, 265). According to this definition one could potentially name thousands of 'races'. In contrast, Sesardic writes of "the four racial groups (white, African American, East Asian and Hispanic)" (2010, 153). Dobzhansky would not have accepted this. He only endorsed weak racial naturalism.

This distinction between a weak and a strong version of racial naturalism may shed some light on the famous debate between Livingstone and Dobzhansky. Dobzhansky ended his response to Livingstone with this thought:

The multiplication of racial or sub-specific names has gone beyond the limits of convenience in the human and in some animal species. This was bound to provoke a reaction, and up to a point this was salutary. But if the reaction goes too far in its protest it breeds confusion. To say that mankind has no races plays into hands of race bigots, and this is least of all desirable when the "scientific" racism attempts to rear its ugly head. (Livingstone and Dobzhansky 1962, 280)

Livingstone was incensed by these final remarks. He wrote that they were, 
incompetent, irrelevant, and immaterial. The fact that some crank may make political hay of a biological fact, concept, or theory is no criterion of the validity of any of these in biological science. I also fail to comprehend how a position which denies the validity of a concept supports anyone using that concept. (Livingstone and Dobzhansky 1962, 280)

One manner in which the denial of a concept can play into the hands of those who use that concept is if the denial is itself absurd. If races can be defined based on any modicum of genetic differentiation, as Dobzhansky suggests, then denying race $i s$ absurd. But that is a very weak definition of race. As Gannett writes, "there is no doubt that Dobzhansky's definition of 'race' as any genetically distinct population facilitated its own demise given that the far less controversial and more technical-sounding 'population' could so easily substitute for it" $(2001,486)$. Sesardic is attempting to revive race on the same definition: "the basic meaning of "race" seems to imply that, due to a common ancestry, members of a given race A will display increased genetic similarity, which will make them in some way genetically different from individuals belonging to another race, B" (Sesardic 2010, 144). This definition is too weak to revive what Sesardic calls "common-sense" racial classification because any groups (including neighbouring towns, socio-economic groups, etc.) that have reduced geneflow could be racialised. It is going to be hard to convince scientists, philosophers, laypeople - anyone really - that this definition of 'race' should be adopted.

My hope is that this discussion provides a sort of 'guide for the perplexed'. I have focused on the rhetorical strategies of race naturalists, but this is not to suggest that social constructionists have not contributed to the confusion in the race debate. In the attempt to distance race from biology, many social constructionists have shied away from discussing human variation, with the result that race naturalists misinterpret them as diversity deniers. But the rhetorical landscape of racial naturalism is much more difficult to traverse. For instance Sesardic both valorises scientists and warns us not to listen to them:

Given this smoke and mirror situation in the debate about such a politicized issue as race, where emotions run high and where huge dangers of a wrong step are obvious to everyone, do not take at face value what scientists merely say about these topics. Instead, look at what they actually do about it in their real work. (Sesardic 2010, 157) 
There are situations where observing action is more instructive than listening to words. Folk wisdom tells us that this is a good idea around partners who are suspected of cheating. It could also be helpful, as Sesardic proposes, when political correctness may obscure actual opinion. It is certainly useful for Sesardic's argument, as anthropologists do sometimes use racial classification in their "real work". But in the case of forensic anthropology the scientists - Sauer (1992) and Ousley et al. (2009) - are telling us why, even though it may look like their work supports racial naturalism, it most emphatically does not. We should at least hear them out.

When scientists appear to side with racial naturalism Sesardic does seem content to take at face value what they "merely" say about race. He pits scientists against philosophers, but this is a false dialectic:

Here is another example of conflicting statements coming from philosophers and working scientists. Philosophers: "Assigning an individual to a race does not buy the inferential power you are usually warranted to expect from a biological kind term" (Machery and Faucher 2005, 1209). Geneticists: "It may be possible to infer something about an individual phenotype from knowledge of his or her ancestry" (Witherspoon et al. 2007, 358). (Sesardic 2010, 156)

It is strange that Sesardic sees these two statements as conflicting. I agree with both statements, and so, I think, would Machery, Faucher, and Witherspoon et al. As Machery and Faucher write, "the concept of race-i.e., the belief that a classification based on skin color and other skin-deep properties like body shape or hair style maps onto meaningful, important biological kinds - is a pseudo-biological concept that has been used to justify and rationalize the unequal treatment of groups of people by others" (Machery and Faucher 2005, 1208). The claim is not, contra Witherspoon et al., that it is impossible to infer anything about a person's phenotype from knowledge about their ancestry. You do not need to be a scientist to know that you can infer something about, for example, skin colour from knowledge of an individual's ancestry. I can infer, with a fairly high probability, that a person with subSaharan African ancestry will have dark skin. If racial naturalism is the position that it is "possible to infer something about an individual phenotype from knowledge of his or her ancestry" then we should all be race naturalists. But since this view does not contrast with social constructionism, which takes human variation as a given (but sees tradition racial 
categories as poorly descriptive of that variation) racial naturalism should be associated with a stronger position. The problem with the stronger position is that it is false.

\section{Conclusion}

Social constructionists about race can no longer simply cite Lewontin's 1972 in defence of their view. The debate has moved on. Yet recent attempts to revive race as a biological category - among which Sesardic's 2010 has been one of the most sophisticated and forceful - fail to stand up to critical scrutiny. Race offers a poor, misleading representation of human biological diversity. Does this mean that race is biologically meaningless? Well, it depends on what one means by that. If it means that race fails to capture the most basic features of human biological diversity - our predominantly clinal variation, the richness of diversity within sub-Saharan Africa - then yes, race is biologically meaningless. If it means that race has connection whatsoever with biology - that, say, 'blacks' are just as likely to have blue eyes as brown eyes - then, no, race is not biologically meaningless. But I doubt that the people who believe this latter claim - Sesardic's 'pure social constructionists' - actually exist.

Sesardic oscillates between defending a weak version of racial naturalism against 'pure' social constructionism, and motivating a stronger project of racial science, which sees traditional racial groupings as objective and non-arbitrary - good categories to do science with. As I have argued, the first project is misguided, because nobody in the debate actually holds the breathtakingly mad view that 'race' is entirely divorced from biology, and the second, stronger project should be abandoned, because it is not supported by the relevant studies of human biological diversity.

\section{Acknowledgements}

This paper has benefited greatly from helpful comments by Paul Griffiths, Maureen O'Malley and Karola Stotz. I would like to thank participants of the 2012 Postgenomic Perspectives on Human Diversity workshop and the 2012 AAHPSSS conference for their useful feedback. I am also grateful to Pierrick Bourrat, David Braddon-Mitchell, Kristie Miller, Dominic Murphy, Frances Olive, Karl Rollings, Isobel Ronai, Luke Russell, Elena Walsh and John Wilkins for their valued comments on earlier versions of this work. Thanks also to Greg 
Radick for suggesting and organising to publish this paper as a part of a dialogue. This research was supported under Australian Research Council's Discovery Projects funding scheme DP0878650 and an APA through the University of Sydney.

\section{References}

Andreasen RO (2004) The cladistic race concept: a defense. Biol Philos 19:425-442

Bamshad M, Wooding S, Salisbury BA, Stephens JC (2004) Deconstructing the relationship between genetics and race. Nat Rev Genet 5:598-609

Barbujani G (2005) Human races: classifying people vs understanding diversity. Curr Genomics 6:215-226

Dobzhansky T (1944) On species and races of living and fossil man. Am J phys Anthr 2:251265

Edwards AWF (2003) Human genetic diversity: Lewontin's fallacy. Bioessays 25:798-801

Gannett L (2001) Racism and human genome diversity research: the ethical limits of "population thinking”. Phil Sci 68:479-492

Gannett L (2004) The biological reification of race. Brit J Philos Sci 55:323-345

Gannett L (2010) Questions asked and unasked: how by worrying less about the 'really real' philosophers of science might better contribute to debates about genetics and race. Synthese 177:363-385

Hochman, A (forthcoming). Against the new racial naturalism. The Journal of Philosophy.

Huxley JS (1938) Species formation and geographical isolation. Proc Linn Soc London $150: 253-264$

Kitcher P (2007) Does 'race' have a future? Philos Public Aff 35:293-317

Lee SSJ, Mountain J, Koenig BA (2001) Meanings of "race" in the new genomics: implications for health disparities research. Yale J Health Policy Law Ethics 1:33-75

Leroi AM (2005) A family tree in every gene. J Gen 84:3-6

Lewontin RC (1972) The apportionment of human diversity. Evol Biol 6:381-398

Li JZ, Absher DM, Tang H, Southwick AM, Casto AM, Ramachandran S, Cann HM, Barsh GS, Feldman M, Cavalli-Sforza LL (2008) Worldwide human relationships inferred from genome-wide patterns of variation. Sci 319:1100-1104

Livingstone FB, Dobzhansky T (1962) On the non-existence of human races. Curr Anthropol 3:279-281 
Machery E, Faucher L (2005) Social construction and the concept of race. Phil Sci 72:12081219

Mitton JB (1977) Genetic differentiation of races of man as judged by single-locus and multilocus analyses. Am Nat 111:203-212

Ousley S, Jantz R, Freid D (2009) Understanding race and human variation: why forensic anthropologists are good at identifying race. Am J Phys Anthropol 139:68-76

Oyama S (1985) The ontogeny of information: developmental systems and evolution. Cambridge University Press, Cambridge

Pigliucci M, Kaplan J (2003) On the concept of biological race and its applicability to humans. Phil Sci:1161-1172

Risch N, Burchard E, Ziv E, Tang H (2002) Categorization of humans in biomedical research: genes, race and disease. Genome Biol 3:1-12

Rosenberg NA, Mahajan S, Ramachandran S, Zhao C, Pritchard JK, Feldman MW (2005) Clines, clusters, and the effect of study design on the inference of human population structure. PLoS Genet 1:661-671

Rosenberg NA, Pritchard JK, Weber JL, Cann HM, Kidd KK, Zhivotovsky LA, Feldman MW (2002) Genetic structure of human populations. Sci 298:2381-2385

Sauer NJ (1992) Forensic anthropology and the concept of race: If races don't exist, why are forensic anthropologists so good at identifying them? Soc Sci Med 34:107-111

Schwartz RS (2001) Racial profiling in medical research. N Engl J Med 344:1392-1393

Serre D, Pääbo S (2004) Evidence for gradients of human genetic diversity within and among continents. Genome Res 14:1679-1685

Sesardic N (2010) Race: a social destruction of a biological concept. Biol Philos 25:143-162

Simpson GG (1943) Criteria for genera, species, and subspecies in zoology and paleozoology. Ann N Y Acad Sci 44:145-178

Snow, C. C., Hartman, S., Giles, E., Young, F. A. (1979) Sex and race determination of crania by calipers and computer: a test of the Giles and Elliot discriminant functions in 52 forensic science cases. J Forensic Sci 24:448-459

Tang H, Quertermous T, Rodriguez B, Kardia SLR, Zhu X, Brown A, Pankow JS, Province MA, Hunt SC, Boerwinkle E (2005) Genetic structure, self-identified race/ethnicity, and confounding in case-control association studies. Am J Hum Genet 76:268-275

Taylor P (2011) Rehabilitating a biological notion of race? A response to Sesardic. Biol Philos 26:469-473 
Tishkoff SA, Reed FA, Friedlaender FR, Ehret C, Ranciaro A, Froment A, Hirbo JB, Awomoyi AA, Bodo JM, Doumbo O (2009) The genetic structure and history of Africans and African Americans. Sci 324:1035-1044

Witherspoon DJ, Wooding S, Rogers AR, Marchani EE, Watkins WS, Batzer MA, Jorde LB (2007) Genetic similarities within and between human populations. Genet 176:351-359

Yu N, Chen FC, Ota S, Jorde LB, Pamilo P, Patthy L, Ramsay M, Jenkins T, Shyue SK, Li WH (2002) Larger genetic differences within Africans than between Africans and Eurasians. Genet 161:269-274 